\title{
Degradation of Polycyclic Aromatic Hydrocarbon Pyrene by Biosurfactant-Producing Bacteria Gordonia cholesterolivorans AMP 10
}

\author{
${ }^{\circledR}$ Tri Handayani Kurniati ${ }^{1}$, Iman Rusmana ${ }^{2}$, Ani Suryani ${ }^{3}$, Nisa Rachmania Mubarik ${ }^{2}$
}

DOI: 10.15294/biosaintifika.v8i3.6448

${ }^{1}$ Department of Biology, Faculty of Mathematics and Natural Sciences, Universitas Negeri Jakarta, Indonesia ${ }^{2}$ Department of Biology, Faculty of Mathematics and Natural Sciences, Institut Pertanian Bogor, Indonesia ${ }^{3}$ Department of Industrial Technology, Faculty of Agriculture Technology, Institut Pertanian Bogor, Indonesia

\section{History Article}

Received 22 June 2016 Approved 6 August 2016 Published 24 December 2016

\section{Keywords:}

biosurfactant; emulsification index (E24);

G. cholesterolivorans; pyrene; surface tension

\begin{abstract}
Pyrene degradation and biosurfactant activity by a new strain identified as Gordonia cholesterolivorans AMP 10 were studied. The strain grew well and produced effective biosurfactants in the presence of glucose, sucrose, and crude oil. The biosurfactants production was detected by the decreased surface tension of the medium and emulsification activity. Analysis of microbial growth parameters showed that AMP10 grew best at $50 \mu \mathrm{g} \mathrm{mL}-1$ pyrene concentration, leading to $96 \%$ degradation of pyrene within 7 days. The result of nested PCR analysis revealed that this isolate possessed the nahAc gene which encodes dioxygenase enzyme for initial degradation of Polycyclic Aromatic Hydrocarbon (PAH). Observation of both tensio-active and emulsifying activities indicated that biosurfactants which produced by AMP 10 when grown on glucose could lower the surface tension of medium from 71.3 $\mathrm{mN} / \mathrm{m}$ to $24.7 \mathrm{mN} / \mathrm{m}$ and formed a stable emulsion in used lubricant oil with an emulsification index (E24) of 74\%. According to the results, it is suggested that the bacterial isolates $G$. cholesterolivorans AMP10 are suitable candidates for bioremediation of PAH-contaminated environments.
\end{abstract}

\section{How to Cite}

Kurniati, T. H., Rusmana, I. Suryani, A. \& Mubarik, N. R. (2016). Degradation of Polycyclic Aromatic Hydrocarbon Pyrene by Biosurfactant-Producing Bacteria Gordonia cholesterolivorans AMP 10. Biosaintifika: Journal of Biology \& Biology Education, 8(3), 336-343.

(C) 2016 Universitas Negeri Semarang

$\triangle$ Correspondence Author:

p-ISSN 2085-191X

e-ISSN 2338-7610

E-mail: trihandayanik@gmail.com 


\section{INTRODUCTION}

One of the major environmental problems today is hydrocarbon contamination which could be derived from natural and anthropogenic process. Although the natural process could contribute to hydrocarbon release into the environment, human activities as it in petroleum and petroleum products industry is a primary cause of pollution of water and soil. Petroleum is a liquid mixture consisting of complex hydrocarbons (Das \& Chandran, 2011; Jahangeer \& Kumar, 2013).

Oil spillage and oil pollution in the environment have been a threat to the ecosystem and human being through the transfer of toxic organic materials including polycyclic aromatic hydrocarbon (PAH). PAH are organic molecules composed of two or more aromatic (benzene) rings which are fused together in various structural configurations. PAHs contamination is a severe environmental concern since this compounds are the ubiquitous persistent contaminant that highly toxic, mutagenic and carcinogenic. Inputs of PAHs from various sources such as forest fires, volcano eruption, oil spills, ship traffic, burning of fossil fuels, urban runoff manufacture of gas and coal tar, wood processing, escaped automobile gasoline, fuel-burning kitchen stove, and industrial effluents have caused significant accumulation of PAHs in the environment (Luan et al., 2006; Fernandez-Luqueno et al., 2011).

In Jakarta bay Indonesia, the content of $\mathrm{PAH}$ at March 2011 ranged from 1.92 to 115.39 ppm in sediment and 104.61 to $474.68 \mathrm{ppm}$ in seawater. The main sources of those PAH was derived from combustion of organic materials, burning of fossil fuels, and the oil spills (Ahmad, 2012). The total concentrations of the 16 PAHs in in sediment samples of an industrial port in the southern Kaohsiung Harbor of Taiwan varied from 4,425 to $51,261 \mathrm{ng} \mathrm{g}^{-1}$, with a mean concentration of $13,196 \mathrm{ng} \mathrm{g}^{-1}$. The PAHs concentration is relatively high in the river mouth region, and gradually diminishes toward the harbor region (Dong, 2012). A similar study by (Wang et al., 2014) showed that PAH concentrations in Coastal sediments in the northern Gulf of Mexico ranged from 100 to $856 \mathrm{ng} \mathrm{g}^{-1}$.

Pyrene which has four benzene rings is included in a list of PAHs priority pollutants by the United States Environmental Protection Agency (US EPA). It has a low biodegradability and high persistence in the environment. Pyrene is a by-product of gasification processes and other incomplete combustion processes. It is highly recalcitrant and resistant to microbial degradation due to its chemical structure (Ceyhan, 2012). The structure of pyrene is found in the molecule of carcinogenic PAHs.

Bioremediation is the promising method for the treatment of contaminated sites since it is to be an economical and efficient alternative method to other remediation processes such as chemical or physical ones. Bioremediation functions basically on biodegradation by microorganisms. Many indigenous microorganisms in water and soil are capable of degrading hydrocarbon contaminants including pyrene. Mycobacterium was published as the first bacterium able to completely degrade pyrene in pure culture (Heitkamp et al., 1988). Some other bacteria were also reported as pyrene degrading bacteria, such as Pseudomonas saccharophila P15, Pseudomonas stutzeri P16, Bacillus cereus P21, Sphingomonas yanoikuyae R1(Kazunga \& Aitken, 2000), an enteric bacterium Leclercia adecarboxylata (Sarma et al., 2004), Mycobacterium vanbaalenii PYR-1 (Kim et al., 2007), Proteus vulgaris (Ceyhan, 2012), Bacillus subtilis C19 (Wijanarko et al., 2012), Corynebacterium sp., Nocardia sp., Pseudomonas sp., Rhodococcus sp. and Micrococcus sp.(Kafilzadeh et al., 2012).

Nevertheless, biodegradation of PAHs in contaminated sites is a slow process due to the low bioavailability of these persistent contaminants (Das \& Chandran, 2011, Shokrollazadeh, 2012). Microorganisms including bacteria may excrete biosurfactants. This compound could enhance the bioavailability of PAHs and accelerate the bioremediation process. In our previous study, nine biosurfactant producing bacteria were isolated from oil contaminated soil. The objective of this study was to determine of the growth and degradation potential of those bacterial isolates on pyrene.

\section{METHODS}

\section{Microorganisms and culture conditions}

Bacterial isolates used in this study were obtained from oil polluted soil in Jakarta Bay. All isolates were confirmed positive as biosurfactant producing bacteria based on a test performed in the previous study (data not shown). The mineral salt medium (MSM) was used as a basal medium both for growth and degradation experiment. This medium was composed of $(\mathrm{g} / \mathrm{L}): \mathrm{KH}_{2} \mathrm{PO}_{4}$ $3.0 \mathrm{~g}, \mathrm{Na}_{2} \mathrm{HPO}_{4} 6.0 \mathrm{~g}, \mathrm{NH}_{4} \mathrm{Cl} 1.0 \mathrm{~g}, \mathrm{NaCl} 0.5 \mathrm{~g}$ and $1 \mathrm{M} \mathrm{MgSO} 41.0 \mathrm{ml}$. This medium also contained $2.5 \mathrm{ml}$ of a trace element as follows $(\mathrm{g} / \mathrm{L})$ : $23 \mathrm{mg}$ of $\mathrm{MnCl}_{2} \cdot 2 \mathrm{H}_{2} \mathrm{O}, 36 \mathrm{mg}$ of $\mathrm{CoCl}_{1} \cdot 6 \mathrm{H}_{2} \mathrm{O}$, $30 \mathrm{mg}$ of $\mathrm{MnCl}_{4} \cdot \mathrm{H}_{2} \mathrm{O}, 31 \mathrm{mg}$ of $\mathrm{H}_{3} \mathrm{BO}_{3}, 10 \mathrm{mg}$ of $\mathrm{CuCl}_{2} \cdot 2 \mathrm{H}_{2} \mathrm{O}, 30 \mathrm{mg}$ of $\mathrm{Na}_{2} \mathrm{MoO}_{4} \cdot 2 \mathrm{H}_{2} \mathrm{O}, 20 \mathrm{mg}$ of 
$\mathrm{NiCl}_{2} \cdot 6 \mathrm{H}_{2} \mathrm{O}$ and $50 \mathrm{mg} \mathrm{ZnCl}$ with $\mathrm{pH} 7.0(\mathrm{Ku}-$ mar et al., 2006).

Bacterial growth on solid medium supplemented with hydrocarbon

MSM agar was prepared by added $15 \mathrm{~g} / 1$ of agar and was sterilised $\left(121^{\circ} \mathrm{C}\right.$ for $\left.20 \mathrm{~min}\right)$ prior to the addition of PAH as a sole carbon source. The stock solutions of pyrene were made in acetone. The ability of isolates to grow in solid medium was tested by spreading $100 \mu \mathrm{L}$ of $24 \mathrm{~h}$ bacterial culture in Nutrient Broth to MSM agar supplemented with pyrene and incubated at $30^{\circ} \mathrm{C}$. Medium without inoculum was used as negative control. Growth on pyrene in the solid media was considered positive by the appearance of the colony at the surface of the medium.

\section{Extraction, PCR Amplification and DNA Sequencing of 16s rRNA Gene}

The extracted DNA was used as a template to amplify the $16 \mathrm{~S}$ rRNA genes by PCR with the universal forward primer $63 \mathrm{f}$ (59-CAGGCC TAA CAC ATG CAA GTC-39) and reverse primer 1387r (59-GGG CGG WGT GTA CAA GGC-39) described by Marchesi et al. (1998). DNA was amplified by KAPA Robust 2 G (KAPA Biosystem). PCR reaction $(25 \mu \mathrm{l})$ contained 1.25 $\mu 1$ of each primer, $1.50 \mu 1$ of template DNA, 12.5 $\mu 1$ KAPA Robust 2G PCR Kit and brought to 25 $\mu \mathrm{l}$ of deionized water. The amplification was performed in a thermal cycler (Takara PCR Thermal Cycler Dice TP600). Amplification conditions included a denaturation step for $5 \mathrm{~min}$ at $95^{\circ} \mathrm{C}$ followed by 35 cycles consisting of $15 \mathrm{~s}$ at $94^{\circ} \mathrm{C}, 30 \mathrm{~s}$ at $53^{\circ} \mathrm{C}$ and $60 \mathrm{~s}$ at $72^{\circ} \mathrm{C}$. The PCR products were analysed by electrophoresis in $1.7 \%$ agarose gel.

\section{Determination of bacterial growth and PAH degradation in liquid media}

The selected isolates AMP 10 was grown in 250-ml flasks containing $100 \mathrm{ml}$ of MSM supplemented with pyrene at concentration $50 \mathrm{mg} / \mathrm{L}$ and $100 \mathrm{mg} / \mathrm{L}$. The flasks were inoculated with $5 \%(\mathrm{v} / \mathrm{v})$ inoculum at final concentration $10^{4} \mathrm{co}-$ lony forming unit $(\mathrm{cfu} / \mathrm{mL})$ and were incubated at room temperature on a rotary shaker (100 rpm) for 7 days. In order to investigate the growth of isolates, a culture solution were taken out every $24 \mathrm{~h}$ of incubation and inoculated in plate count agar by pour plate method. The growth of isolates was measured by counting colony forming unit of the culture. The residual PAH from culture flask was determined by taking $1 \mathrm{~mL}$ of culture and centrifuged at $10.000 \mathrm{rpm}$ for 10 minutes, and supernatant was separated for GC-MS analysis.

\section{Detection of the gene encoding PAH-degrad- ing dioxygenase}

Bacterial DNA was extracted by the DNA extraction kit (Geneaid). The presence of the initial dioxygenase genes in AMP10 isolate was detected based on PCR amplification using PCR kit (KAPA Robust 2G, Kapa Biosystem). The primers for the detection of $n a h A c$ gene were listed in Table 1.

The PCR conditions were: $94^{\circ} \mathrm{C}$ for $3 \mathrm{~min}$, followed by 40 cycles consisting of $94^{\circ} \mathrm{C}$ for 45 s, $55^{\circ} \mathrm{C}$ for $45 \mathrm{~s}$ and $72^{\circ} \mathrm{C}$ for $45 \mathrm{~s}$, with a final extension period at $72^{\circ} \mathrm{C}$ for $5 \mathrm{~min}$. The PCR conditions for the nested round were similar to the first, except that 30 cycles were used. The PCR products were checked on $1 \%$ agarose gel electrophoresis.

\section{Measurement of emulsifying activity and sur- face tension}

An aliquot $(1.0 \mathrm{ml})$ of inoculum was transferred to $250 \mathrm{ml}$ Erlenmeyer flask containing 50 $\mathrm{ml}$ of MSM and $1 \%(\mathrm{v} / \mathrm{v})$ carbon sources. Three different carbon source used in the flask culture were glucose, sucrose, and crude oil. Incubation was carried out on a rotary shaker at $100 \mathrm{rpm}$ in room temperature for 5 days. Culture samples were taken at the end of the incubation period, and supernatant of culture was obtained after centrifugation at $10.000 \mathrm{rpm}$ for 20 minutes.

The emulsification index (E24) of culture samples was determined by adding $2 \mathrm{~mL}$ of supernatant and $2 \mathrm{~mL}$ used lubricating oil to a test

Table 1. PCR primer for the detection of the initial PAH-degrading dioxygenase gene

\begin{tabular}{ccccc}
\hline nahAc-like primer & Sequences & $\begin{array}{c}\text { Product size } \\
(\mathrm{bp})\end{array}$ & Reference \\
\hline \multirow{2}{*}{ First round } & Nah-for & TGCMVNTAYCAYGGYTGG & 937 & \\
& Nah rev-1 & CCCGGTARWANCCDCKRTA & & Zhou et al. (2006) \\
Nested round & Nah-for & TGCMVNTAYCAYGGYTGG & 317 & \\
& Nah rev-2 & CRGGTGYCTTCCAGTTG & & \\
\hline
\end{tabular}


tube. The mixture was vortexed for 1 minute and allowed to stand for 24 hours. The height of the stable emulsion layer was measured, and the E24 value was calculated as the percentage of height of emulsified layer $(\mathrm{cm})$ divided by the total height of the liquid column (Bodour et al., 2004).

For surface tension measurements, supernatant was transferred to a glass tube and a capillary tube was dipped in this liquid. This procedure was done at a room temperature. The height reached by the liquid trough a capillary tube was measured and surface tension calculated according to the following formula (ViramontesRamos, 2010):

Where :

$$
\gamma=1 / 2 \operatorname{rh} \delta g
$$

$\gamma=$ Surface tension $(\mathrm{mN} / \mathrm{m})$;

$\delta=$ Density $(0.99 \mathrm{~g} / \mathrm{mL})$;

$\mathrm{g}=\operatorname{gravity}(980 \mathrm{~cm} / \mathrm{s} 2)$;

$\mathrm{r}=$ capillary radius $(0.09 \mathrm{~cm})$;

$\mathrm{h}=$ height of the liquid column $(\mathrm{cm})$.

Both the surface tension and EI measurements were performed in triplicate.

\section{RESULTS AND DISCUSSION}

A four of the nine bacterial isolates which were obtained from oil contaminated soil in Jakarta bay have the ability to grow in MSM agar plate supplemented with PAH pyrene as a sole carbon source (Table 2). This result indicates that these isolates could degrade the PAH compounds. Pyrene is a common PAH obtained from coal tar and frequently used as a chemical intermediate. They were considered as priority pollutant in the environment because of their toxicity. Due to the hazardous effect of PAH, it is necessary to clear up or lowering the concentration of these substances in the environment. Ahmed et al. (2012), described that bacteria have the unique feature in rapidly adapting to toxic environments. The metabolic diversity and plasticity of bacteria allow them to degrade organic pollutants and helps in the mineralisation of these compounds.

As the result in Table 2, four isolates could grow in MSM solid medium with pyrene. Based on the growth rate in $\mathrm{PAH}$ medium and performance in the screening of biosurfactant production from the previous study, AMP10 isolates was selected for further analysis. Although RIP43 isolates has the same type of growth with AMP10 isolates (moderate), it was not selected because it has lower emulsification index value than AMA 10 isolates in biosurfactant preliminary screening test (data not shown). The growth of bacteria on hydrocarbons is usually accompanied by the production of biosurfactants that improve the affinity of the cells to substrates and facilitate the hydrocarbon bioavailability and degradation process The effect of biosurfactant production by hydrocarbon-degrading bacteria itself may be beneficial, promising and more practical than adding purified biosurfactant for field bioremediation application. A hydrocarbon-degrading bacterium having the ability to produce extracellular biosurfactant can facilitate the oil-microbe contact (Kumar et al., 2006; Sneha et al., 2012).

Table 2. Growth of bacterial isolates on MSM agar plate with pyrene

\begin{tabular}{cccc}
\hline isolates & Gram type & $\begin{array}{c}\text { Growth in } \\
\text { pyrene }\end{array}$ & $\begin{array}{c}\text { Type of } \\
\text { growth* }\end{array}$ \\
\hline AMA9 & negative & - & - \\
AMP10 & positive & + & moderate \\
CHA60 & negative & - & - \\
CHA63 & negative & - & - \\
CHP64 & negative & + & slow \\
CHP29 & positive & + & slow \\
CRA32 & positive & - & - \\
CRA7 & negative & - & - \\
RIP43 & positive & + & moderate \\
\hline
\end{tabular}

+: positive growth -: no growth

*) Fast: < 7 days, moderate : 7-14 days, slow : > 14 days

Identification of AMP10 isolate was performed by $16 \mathrm{~S}$ rRNA analysis using forward primer 63f (59-CAGGCC TAA CAC ATG CAA GTC-39) and reverse primer 1387r (59-GGG CGG WGT GTA CAA GGC-39) described by Marchesi et al. (1998). The expected size of the fragment sequenced from the 16S rRNA gene was $1300 \mathrm{bp}$ (Figure 2a). Sequence analysis of $16 \mathrm{~S}$ rDNA gene showed that AMP 10 was identified as Gordonia cholesterolivorans with 99\% identity compared to the NCBI databases.

The genus Gordonia, belongs to the mycolic acid-containing group of the Actinomycetes and to the suborder Corynebacterineae. Members of Gordonia are important in bioremediation processes due to their capacity to degrade hydrocarbons and natural compounds which are not readily biodegradable. Most species of this genus have been known to degrade xenobiotics, environmental pollutants, or otherwise slowly biodegradable natural polymers (Arenskotter, 2004). Gordonia sp. strain BS29 has the ability to grow on aliphatic hydrocarbons and produces two different types of surface active compounds (SACs): 
extracellular bioemulsans and cell-bound biosurfactants (Franzetti et al., 2009). Some species of genus Gordonia has been known able to degrade xenobiotic contaminants or macromolecules such as rubber, (di) benzothiophene, and alkanes. G. cholesterolivorans was an aerobic, Gram-positive staining, non-motile and non-spore-forming bacteria (Drzyzga et al., 2009).

Bacterial growth and degradation ability were studied at 50 and $100 \mathrm{mg} / \mathrm{L}$ of initial substrate concentrations. Growth of $G$. cholesterolivorans AMP10 both in $50 \mathrm{mg} / \mathrm{L}$ and $100 \mathrm{mg} / \mathrm{L}$ concentration of pyrene showed a similar pattern (Fig 1). It is observed that the highest cell number obtained on day 5 were $3.3 \times 10^{9} \mathrm{cfu} / \mathrm{mL}$ and $6.4 \times 10^{8} \mathrm{cfu} / \mathrm{mL}$ in $50 \mathrm{mg} / \mathrm{L}$ and $100 \mathrm{mg} / \mathrm{L}$ of pyrene concentration, respectively. Increasing the number of cells indicated that these isolates capable of using pyrene as a source of carbon and energy.

The biodegradation of PAH has been widely studied, and many bacterial strains have been isolated for their ability to degrade PAH. A biodegradation study of PAH by Guo et al. (2010) revealed that more than $80 \%$ of each of the three PAHs (Pyrene, Phenanthtene and Fluoranthene) was degraded by Mycobacterium after 7 days and pyrene was completely degraded by three Mycobacterium strains (SBSW, YOWG and SKEY) after 14 days. Mycobacterium showed higher ability in degrading the three PAHs than genera Sphingomonas, Rhodococcus, Paracoccus and Pseudomonas. A similar study by Kafilzadeh et al. (2012) reported pyrene degradation value by $M y$ cobacterium sp and Corynebacterium sp. were $89.1 \%$ and $79.4 \%$, respectively. However, according to our knowledge, the degradation of pyrene by Gordonia cholesterolivorans has not been reported so far.

The strain G. cholesterolivorans AMP 10 showed pyrene degradation about $93.8 \%$ at concentration $50 \mathrm{mg} / \mathrm{L}$ and $86.5 \%$ at concentration $100 \mathrm{mg} / \mathrm{L}$ after 5 days and increase to $96.6 \%$ and $91.7 \%$ after 7 days of incubation (Figure 2). This result was higher than that previously reported. We suggest that the biosurfactant produced by this isolate may assist the bacteria to attach the pyrene for degradation.

Degradation of PAHs was mostly carried out by the dioxygenase enzymes produced by the $\mathrm{PAH}$-degrading bacteria in aerobic conditions. The initial dioxygenases which responsible for attacking the aromatic ring structures of PAH are considered as the key enzymes in PAH degradation activity. The nahAc gene that encodes a component of naphthalene dioxygenases can be used to determine of PAH-dioxygenase genes. This gene serves as a potential biomarker for PAH degradation activity because of its highly conserved (Park \& Crowley, 2006; Yuliani et al., 2012)

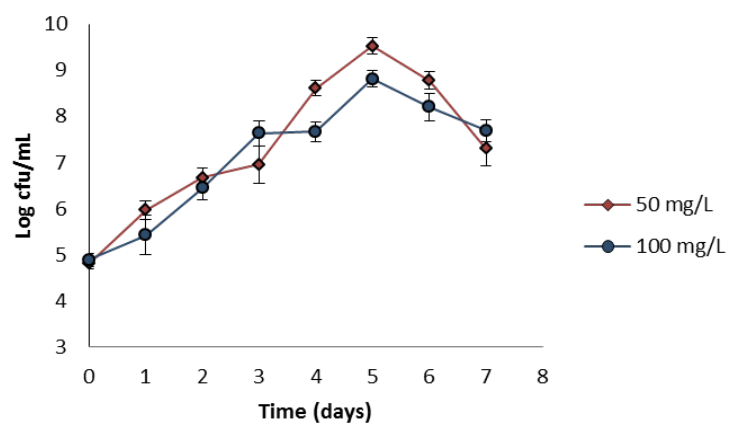

Figure 1. Growth of $G$. cholesterolivorans AMP 10 in liquid MSM supplemented with pyrene

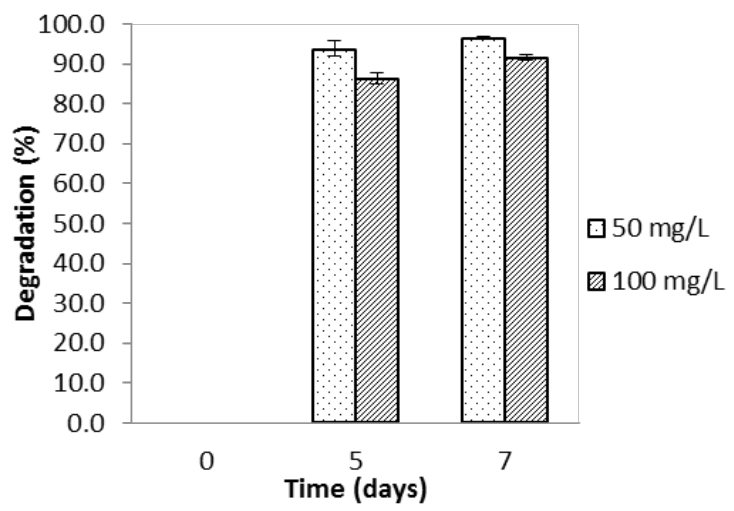

Figure 2. Degradation of pyrene in liquid MSM by $G$. cholesterolivorans AMP 10

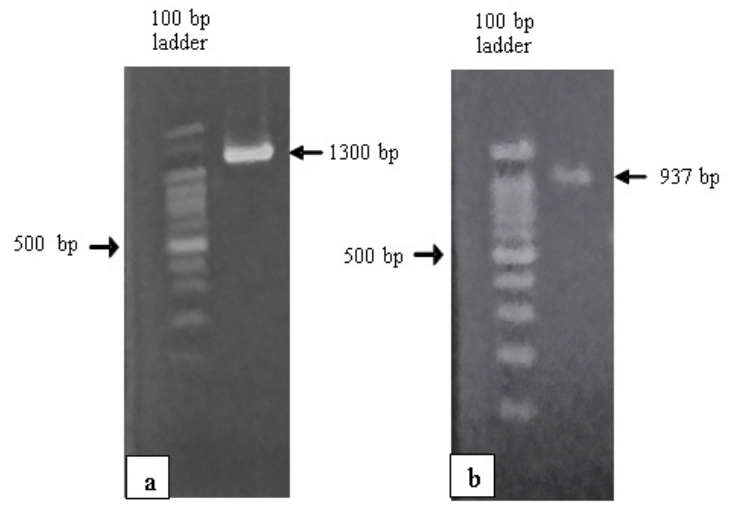

Figure 3. Agarose gel electrophoresis of AMP 10 PCR products. a. $16 \mathrm{~S} \mathrm{rDNA}$ (1300 bp); b. NahAc dioxygenase gene (937 bp)

The presence of the initial dioxygenase gene from $G$. cholesterolivorans was detected by nested PCR amplification using nahAc-like primer described by Zhou et al. (2006). These primers amplified DNA fragments of $937 \mathrm{bp}$ (Figure 3b) and $317 \mathrm{bp}$ in nested PCR. However, no PCR 
product was detected in nested round PCR in this study. Yuliani et al. (2012) described that nested round PCR was used as a confirmation step to check dioxygenase gene product from the first round PCR. NahAc gene is highly conserved among different Gram-negative bacteria (Park \& Crowley, 2006). It was obtained from Gram negative bacteria such as Pseudomonas and Burkholderia species (Guo et al., 2010). This study gives a different result that this gene could obtain from $G$. cholesterolivorans which is Gram-positive bacteria. Park \& Crowley (2006) explained that natural horizontal gene transfer could occur between different species that carry this gene. Besides that, the nahAc gene was detected not only in naphthalene degrading bacteria but also in bacteria which could degrade higher molecular weight PAHs including phenanthrene, anthracene, fluoranthene, and pyrene.

Surface activity and emulsification capability of bacterial culture give a strong indication of biosurfactant production (Walter et al., 2010). Surface tension reduction, emulsification property and stabilising capacity are the most important properties of microbial surfactants with potential industrial applications (Ferhat, 2011). Biosurfactant contains hydrophobic and hydrophilic groups that confer the ability to accumulate between fluid phases, thereby reducing surface and interfacial tension at the surface and interface regions (Kapadia \& Yagnik, 2012). Emulsification activity is the ability for a surfactant to form an emulsion under given condition (Cheng et al., 2008). The excellent emulsification property is critical for biosurfactants to be promising in different environmental and industrial applications (Banat et al., 2000)

To confirm the ability of isolates in biosurfactant production, measurement of surface tension and emulsification test were conducted in this study using three different carbon source i.e. glucose, sucrose and crude oil with $1 \%$ concentration each (Fig 4a). Measurement of surface tension and index emulsification (E24) of cell-free culture broth showed that all carbon sources could be used to produce biosurfactant by $G$. cholesterolivorans AMP 10 with surface tension value 26.38$36.64 \mathrm{mN} / \mathrm{m}$ and emulsification capacity 62.91 $75.38 \%$ (Table 2). Used lubricating oil was used in this study to measure emulsification capacity of supernatant (Fig 4b). According to Cooper \& Zajic (1980), the major criteria used for selecting microbial biosurfactants is their ability to reduce the surface tension $40 \mathrm{mN} / \mathrm{m}^{-1}$ or less, while Willumsen \& Karlson (1997) considered a culture as promising if it has emulsification capacity at least $50 \%$ after $24 \mathrm{~h}$. Biosurfactant is highly variable, depending on the composition of the growth medium that is used to culture the microorganisms.

Table 3. Surface tension and emulsification index (E24) value in different carbon source

\begin{tabular}{ccc}
\hline $\begin{array}{c}\text { Carbon } \\
\text { source }\end{array}$ & $\begin{array}{c}\text { Surface tension } \\
(\mathrm{mN} / \mathrm{m})\end{array}$ & $\begin{array}{c}\text { Emulsification } \\
\text { index }(\mathrm{E} 24)\end{array}$ \\
\hline Glucose & $24.7 \pm 0.00$ & $78.35 \pm 0.38$ \\
Sucrose & $26.2 \pm 0.00$ & $62.91 \pm 2.53$ \\
Crude Oil & $36.4 \pm 2.52$ & $68.98 \pm 2.06$ \\
\hline
\end{tabular}

In this study, glucose was the best carbon source for biosurfactant producing by $G$. cholesterolivorans. It has lowest surface tension and highest emulsification activity compared to sucrose and crude oil (Table 3). The surface tension decreased from 71.3 to $24.7 \mathrm{mN} / \mathrm{m}$ and E24 value obtained was $78.54 \%$. Effect of carbon source on biosurfactant production by Bacillus clausii $5 \mathrm{~B}$ was made by Aparna et al. (2012), glucose as a carbon source showed lowest surface tension value $(30.23 \mathrm{mN} / \mathrm{m})$ compared to sucrose, molasses and glycerol. Similarly, glucose as a carbon source could decrease the surface tension of $P$. aeruginosa MM1011 cell-free culture up to $20 \mathrm{mN} / \mathrm{m}$ (Rashedi, 2006). This current result suggesting that $G$. cholesterolivorans AMP 10 was a potential pyrene degrader and a good biosurfactant producer which could played a major role in bioremediation process.

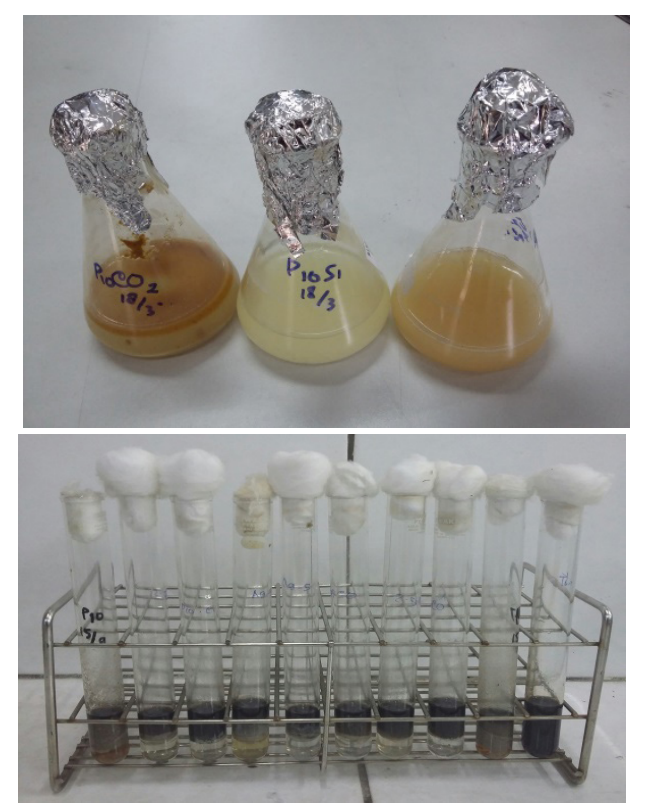

Figure 4. a. Growth of Gordonia cholesterolivorans AMP10 in different carbon source; b. Emulsion 
of cell-free culture in used oil.

\section{CONCLUSION}

The results obtained in the present study showed that the novel biosurfactant-producing bacteria $G$. cholesterolivorans AMP 10 have the ability to degrade pyrene. It has shown a good potential to degrade pyrene as a sole carbon source. This degradation ability was confirmed by nahAc dioxygenase gene product obtained by nested PCR analysis. Biosurfactant production of this isolate was indicated by reduced surface tension of culture medium and high emulsification index (E24) value. Therefore, it can be concluded that G. cholesterolivorans AMP 10 with the capacity to degrade pyrene and at the same time to produce biosurfactant, can find application in bioremediation.

\section{REFERENCES}

Ahmad, F. (2012). Kandungan senyawa polisiklik aromatik hidrokarbon (PAH) di teluk Jakarta. Ilmu Kelautan. 17(4), 199-208.

Ahmed, A. T., Othman, M. A., Sarwade, V. D. \& Gawai, K. R. (2012). Degradation of anthracene by alkaliphilic bacteria Bacillus badius. Environ Pollut, 1(2), 97-104.

Aparna, A., Srinikethan, G. \& Hegde, S. (2012). Isolation, screening and production of biosurfactant by Bacillus clausii 5B. Res Biotechnol, 3(2), 49-56.

Arenskötter, M., Bröker, D. \& Steinbüchel, A. (2004). Biology of the metabolically diverse genus Gordonia. Appl Environ Microbiol, 70(6), 3195-3204.

Banat, I. M., Makkar, R. S, \& Cameotra, S. S. (2000). Potential commercial applications of microbial surfactants. Appl Microbiol Biotechnol, 53(5), 495-508.

Bodour A. A., Guerrero-Barajas, C., Jiorle, B. V., Malcomson, M. E., Paull, A. K., Somogyi, A., Trinh, L. N., Bates, R. B. \& Maier, R. M. (2004). Structure and characterization of flavolipids, a novel class of biosurfactants produced by Flavobacterium sp. strain MTN11. Appl Environ Microbiol, 70(1), 114-120.

Cooper, D. G. \& Zajic, J. E. (1980). Surface-active compounds from microorganisms. Adv Appl Microbiol, 26, 229-253.

Ceyhan, N. (2012). Biodegradation of pyrene by a newly isolated Proteus vulgaris. Sci Res Essays, 7(1), 66-77.

Cheng, K. B., Jian, Z. \& Wang, Z. (2008). Emulsification properties of bacterial biosurfactants native to the Yellow River delta on hexadecane and diesel oil. Biotechnol, 7, 360-370.

Das, N. \& Chandran, P. (2011). Microbial degradation of petroleum hydrocarbon contaminants: an overview. Biotechnol Res Int, 2011, 1-13.

Dong, C. D., Chen, C. F., \& Chen, C. W. (2012). Determination of polycyclic aromatic hydrocarbons in industrial harbor sediments by GC-MS. Int $J$ Environ Res Public Health, 9(6), 2175-2188.

Drzyzga, O., Llorens, J. M. N., de las Heras, L. F., Fernández, E. G., \& Perera, J. (2009). Gordonia cholesterolivorans sp. nov., a cholesteroldegrading actinomycete isolated from sewage sludge. Int J Syst Evol Microbiol, 59(5), 10111015.

Ferhat, S., Mnif, S., Badis, A., Eddouaouda, K., Alouaoui, R., Boucherit, Mhiri N, Moulay-Mostefa N. \& Sayadi, S. (2011). Screening and preliminary characterization of biosurfactants produced by Ochrobactrum sp. 1C and Brevibacterium $s p$. 7G isolated from hydrocarboncontaminated soils. Int Biodeter Biodegr, 65(8), $1182-1188$.

Fernández-Luqueño, F., Valenzuela-Encinas, C., Marsch, R., Martínez-Suárez, C., VázquezNúñez, E., \& Dendooven, L. (2011). Microbial communities to mitigate contamination of PAHs in soil-possibilities and challenges: a review. Environ Sci Pollution Res, 18(1), 12-30.

Franzetti, A., Caredda, P., Ruggeri, C., La Colla, P., Tamburini, E., Papacchini, M. \& Bestetti, G. (2009). Potential applications of surface active compounds by Gordonia sp. strain BS29 in soil remediation technologies. Chemosphere, 75(6), 801-807.

Guo, C., Dang, Z., Wong, Y., \& Tam, N. F. (2010). Biodegradation ability and dioxgenase genes of PAH-degrading Sphingomonas and Mycobacterium strains isolated from mangrove sediments. Int Biodeter Biodegr, 64(6), 419-426.

Heitkamp, M. A., Franklin, W., \& Cerniglia, C. E. (1988). Microbial metabolism of polycyclic aromatic hydrocarbons: isolation and characterization of a pyrene-degrading bacterium. Appl Environ Microbiol, 54(10), 2549-2555.

Jahangeer \& Kumar, V. (2013). An Overview on Microbial Degradation of Petroleum Hydrocarbon Contaminants. Int J Eng Tech Res, 1(8), 34-37.

Kafilzadeh, F., Hoshyaripour, F., Tahery, Y., Azad, H. N. (2012). Bioremediation of pyrene by isolated bacterial strains from the soil of the landfills in Shiraz (Iran). Ann Biol Res, 3(1), 486-494.

Kapadia S. G. \& Yagnik B. N. (2013). Current trend and potential of microbial biosurfactants. Asian $J$ Exp Biol Sci, 4(1),1-8.

Kazunga, C., \& Aitken, M. D. (2000). Products from the incomplete metabolism of pyrene by polycyclic aromatic hydrocarbon-degrading bacteria. Appl Environ Microbiol, 66(5), 1917-1922.

Kim, S. J., Kweon, O., Jones, R. C., Freeman, J. P., Edmondson, R. D., \& Cerniglia, C. E. (2007). Complete and integrated pyrene degradation pathway in Mycobacterium vanbaalenii PYR-1 based on systems biology. J Bacteriol, 189(2), 464-472.

Kumar, M., Leona, V., Materano, A. D. S., Ilzins, O. A., Castro, I. G. \& Fuenmayor, S. L. (2006). Polycyclic aromatic hydrocarbon degradation 
Tri Handayani Kurniati et al. / Biosaintifika 8 (3) (2016) 336-343

by biosurfactant-producing Pseudomonas $s p$ IR1. Z Naturforsch, 61(3-4), 203-212.

Luan, T.G., Yu, K.S.H., Zhong, Y., Zhou, H.W., Lan, C.Y. \& Tam, N.F.Y. (2006). Study of metabolites from the degradation of polycyclic aromatic hydrocarbons (PAHs) by bacterial consortium enriched from mangrove sediments. Chemosphere, 65(11), 2289-2296.

Marchesi, J. R., Sato, T., Weightman, A. J., Martin, T. A., Fry, J. C., Hiom, S. J. \& Wade, W. G. (1998). Design and evaluation of useful bacterium-specific PCR primers that amplify genes coding for bacterial 16S rRNA. Appl Environ Microbiol, 64(2), 795- 799.

Park, J. W., \& Crowley, D. E. (2006). Dynamic changes in nahAc gene copy numbers during degradation of naphthalene in PAH-contaminated soils Appl Microbiol Biotechnol, 72(6), 1322-1329.

Rashedi, H., Jamshidi, E., Assadi, M. M, \& Bonakdarpour, B. (2006). Biosurfactant production with glucose as a carbon source. Chem Biochem Eng Q, 20(1), 99-106.

Sarma, P. M., Bhattacharya, D., Krishnan, S., \& Lal, B. (2004). Degradation of polycyclic aromatic hydrocarbons by a newly discovered enteric bacterium, Leclercia adecarboxylata. Appl Environ Microbiol, 70(5), 3163-3166.

Sneha, K. S., Padmapriya, B., \& Rajeswari, T. 2012. Isolation and screening of biosurfactants produced by Pseudomonas aeruginosa from oil spilled soils. Int J Pharm Biol Arch, 3(2), 321-325.

Shokrollahzadeh, S., Golmohammad, F., \& Shokouhi, H. (2012). Study of Sphingopyxis Isolates in Degradation of Polycyclic Aromatic Hydrocarbons. Chem Eng Trans, 27, 55-60.
Viramontes-Ramos, S., Portillo-Ruiz, M. C., BallinasCasarrubias, M.D.L., Torres-Muñoz, J.V., Rivera-Chavira, B.E. \& Nevárez-Moorillón, G.V. (2010). Selection of biosurfactant/bioemulsifier-producing bacteria from hydrocarbon-contaminated soil. Braz J. Microbiol, 41(3), 668-675.

Walter,V., Syldatk, C, \& Hausmann, R. (2010). Screening Concepts for the Isolation of Biosurfactant Producing Microorganisms. Adv Exp Med Biol 672, 1-13.

Wang, Z., Liu, Z., Xu, K., Mayer, L. M., Zhang, Z., Kolker, A. S., \& Wu, W. (2014). Concentrations and sources of polycyclic aromatic hydrocarbons in surface coastal sediments of the northern Gulf of Mexico. Geochem Trans, 15(1), 1-12.

Wijanarko, A., Yuliani, H., Hermansyah, H., \& Sahlan, M. (2012). Isolation and properties characterization of biosurfactant synthesized by pyrene degrading Bacillus subtilis C19. J. Chem. Chem. Eng, 6(10), 889-896.

Willumsen, P.A., \& Karlson, U. (1996). Screening of bacteria, isolated from PAH-contaminated soils, for production of biosurfactants and bioemulsifiers. Biodeg, 7(5), 415-423.

Yuliani, H. A., Hermansyah, H. E., Sahlan, M. U., \& Wijanarko A. N. (2012). Dioxygenase gene of PAHs degrading Bacillus strains isolated from marine Indonesian environment and its biosurfactant production ability. Int $J$ Pharm Bio Sci, 3(4), 380-390.

Zhou, H. W., Guo, C. L., Wong, Y. S., \& Tam, N. F. Y. (2006). Genetic diversity of dioxygenase genes in polycyclic aromatic hydrocarbon-degrading bacteria isolated from mangrove sediments. FEMS Microbiol Lett, 262(2), 148-157. 